\title{
A history of discoveries and disappearances of the rare annual plant Lythrum thesioides M.Bieb.: new insights into its ecology and biology
}

\author{
Antoine Gazaix a,b , Mario Klesczewskic, Michel-Ange Bouchet ${ }^{\mathrm{d}}$, Manuel Cartereaue, James Molina ${ }^{\mathrm{f}}$, \\ Henri Michaudf, Serge D. Muller' ${ }^{g}$, Lionel Pirsoulc, Perrine Gauthier ${ }^{b}$, Patrick Grillas ${ }^{a}$ and John D. Thompson ${ }^{b}$ \\ ${ }^{a}$ Ecosystem department, restauration team. Tour du Valat Institut de recherche pour la conservation des zones \\ humides méditerranéennes, Arles, France; 'biodiversity and conservation, Centre d'Ecologie Fonctionnelle et Evolutive (UMR 5175), \\ Montpellier, France; 'CEN L-R Conservatoire d'espaces naturels du, Montpellier, France; dBiotope, Mèze, France; elnstitut Mediterranéen de

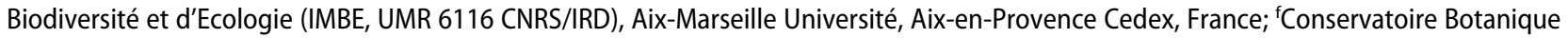 \\ National Méditerranéen de Porquerolles, Montferrier-sur-Lez, France; 9Dynamique de la Biodiversité, Anthropo-écologie, CNRS, Institut \\ des Sciences de l'Evolution (ISE-M), Université de Montpellier, Montpellier, France
}

\section{ABSTRACT}

Mediterranean temporary pools are threatened ecosystems that host a unique plant community, mostly composed of annual species with large and long-lived seed banks. The longevity of their seed bank, the scarcity of their habitat, the small size of their populations and the low frequency of above-ground vegetation result in a low probability of detection of these species. The discovery of new populations of such rare species are thus important for our understanding of the ecology of the temporary pool ecosystem. Lythrum thesioides M.Bieb., 1808 is a very rare annual species of temporary pools and river banks which was thought to be extinct in the South of France until 1998. Here, we review the distribution of the species and report the recent discovery of a population during a targeted search combining historical data on wetland occurrence on a particular geological substrate. We present new information on its autecology, pollen morphology and the karyotype. Only three populations are currently known worldwide for Lythrum thesioides, and only one of these has favorable management conditions. Thus, we outline new conservation perspectives in the context of a targeted search project and the conservation management of one population.

\section{ARTICLE HISTORY}

Received 19 February 2019

Accepted 3 October 2019

\section{KEYWORDS}

(5 à 8): Conservation; rarity; temporary pool;

Mediterranean; ecological

niche; historical ecology

\section{Introduction}

The ecology of Mediterranean temporary pools is characterized by an alternation of winter flooding and summer drought with large inter-annual fluctuations in the relative duration of these phases (Grillas et al. 2004). The particular environmental conditions of these pools have resulted in the presence of a highly specialized flora, with most species having short life cycles - i.e. annual species with high fecundity (Médail et al. 1998) - and large soil propagule banks (seeds, spores) that persist in the soil during unfavorable conditions for germination (Aponte et al. 2010).

The plant communities of Mediterranean temporary pools have stimulated the curiosity and interest of botanists for decades, and are still considered as a floristic "jewel" (Braun-Blanquet 1935; Rhazi et al. 2012). However, Mediterranean temporary pools are a threatened and highly vulnerable ecosystem (Rhazi et al. 2012) and have been designated as a priority habitat of community interest at the European scale (Council of Europe 1992). Indeed, due to their small surface they are easily destroyed and have experienced a dramatic decrease in number and surface area around the Mediterranean region (e.g. Gallego-Fernández et al. 1999; Rhazi et al. 2012) due to agricultural intensification, pollution (including eutrophication), drainage and direct destruction for urbanization (Bouahim et al. 2014).

The longevity of their seed bank, the scarcity of their habitat and their small size and low frequency in aboveground vegetation, result in a low probability of detection of many of the annual species that predominate in Mediterranean temporary pools, making it difficult to assess their abundance, dynamics and distribution (Aponte et al. 2010; Alvarez et al. 2012). A complete inventory of the plant communities of a temporary pool thus requires multiple visits during a single year and over several years that experience contrasting hydrological characteristics (Rhazi et al. 2009). This requires time, botanists and favorable conditions that may only occur one year per decade or even less (Poschlod and Rosbakh 2018). As a result, and despite the interest of botanists for the unique flora of temporary pools, the distribution of many species of this Mediterranean ecosystem remains only partially known. The conservation significance and restoration potential of Mediterranean temporary pools may thus be seriously underestimated at the current time. The discoveries of new populations of rare species are thus important to improving our 
understanding of the ecology of the temporary flooded ecosystem.

Lythrum thesioides M.Bieb., 1808 (Lythraceae) is an erect annual plant (Figure 1) of temporary wetlands. It is highly variable in size, with plant height ranging from 5 to $40 \mathrm{~cm}$ according to hydrological conditions. The leaves are alternate, linear and elongated. The flowers are usually geminate (Figure 1, e), shortly pediculate, each node carrying axillary clusters of (1-) 2 (-4) flowers. The hypanthium is bell-shaped, with a short calyx made of four sepals. The four petals are pink with a purple line down the main vein. The four stamens are included in the hypanthium (Coste 1906). The ovary is superior and the fruit is a capsule (Tutin et al. 1968). The plant is flowering from July to September (Tison et al. 2014). This species is very rare and several elements of its description remain incomplete.

In the 1990s Lythrum thesioides was thought to be extinct from the South of France (Olivier et al. 1995) and in Europe (Morgan and Leon 1992). This species is a representative example of the challenges underlying the conservation of ephemeral plant species in temporary pools. There is however much piecemeal evidence of historical and more contemporary presence of this species in different sites. Therefore, the aims of this article are as follows.
(1) Synthesize the current and historical distribution of $L$. thesioides.

(2) Provide new elements for the botanical description of $L$. thesioides.

(3) Describe recent the 10 plants, 30 fruits were assedtargeted prospections of $L$. thesioides that have been focused on previously known populations and/or habitat suitability based on historical pool presence and geological substrate.

\section{Material and methods}

(1) Distribution of Lythrum thesioides

To produce a map of distribution of Lythrum thesioides observations we examined both herbarium specimens and mentions in Flora and catalogues (Lythrum thesioides or Lythrum geminiflorum Bertol. 1842). Herbarium specimens were examined using the Global Biodiversity Information Facility database (GBIF.org), and the e-Recoltnat programme (MNHN, Paris) for French collections. Other information was obtained or consulted from non-referenced herbariums (Almaty, Bologna, Budapest, Geneva, Saint Petersbourg
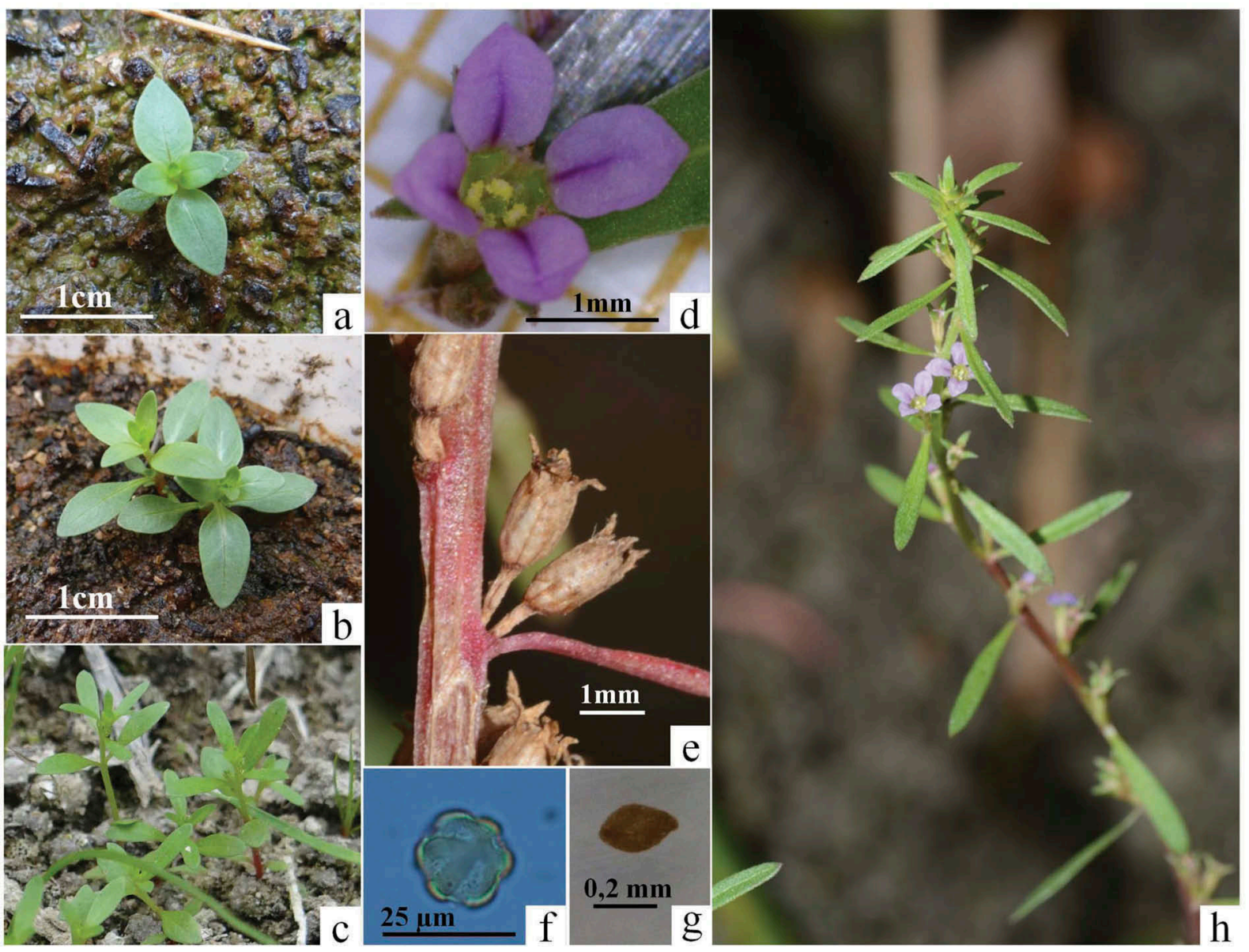

Figure 1. Pictures of Lythrum thesioides. (a,b) Seedlings under light, (c) seedlings under shadow conditions, (d) detailed flower, (e) fruits (geminate, $\odot$ M. Charrier), (f) pollen (๑ S. Muller), (g) seed, (h) flowering stem (๑ M. Charrier). 
and Vienna). Herbarium codes are later on used following Thiers (2019). Floras of the areas concerned by herbarium samples were also consulted where possible.

(2) Species description

\section{Field and culture observations}

In 2015, one individual of Lythrum thesioides was isolated in a greenhouse before flowering, in order to evaluate its ability to accomplish self-pollination. Seeds produced were tested for germination (Gazaix et al. in prep). Pollination was also studied in the field in August 2018 in the Campuget population. A 1-day experiment was done, with 20-min observation per flower, capturing every insect visiting the flower, for a total of 10 observed flowers.

In 2017, 10 flowering individuals cultivated in Camargue (Tour du Valat) were monitored four times a day (7 am, $12 \mathrm{am}, 5 \mathrm{pm}$ and $9 \mathrm{pm}$ ) during a week to evaluate the longevity of individual flowers. On each of the 10 plants, 30 fruits were assessed for the number of seeds, seed length and width (under a binocular microscope) and seed weight, by weighing 10 groups of 30 seeds (weighting scale: Mettler Toledo AG 245).

\section{Pollen description}

For the observation of pollen, 10 flowers of Lythrum thesioides were collected on five individuals grown in pots at the Tour du Valat Biological Station in 2018. Flowers were kept in paper bags prior to analysis. Stamens taken from flowers were submitted to an acetolysis treatment (nine parts of anhydric acetic acid and one part of sulphuric acid at $90^{\circ} \mathrm{C}$ for 3 min; Faegri and Iversen 1989), in order to remove the cellular content and the pectocellulosic intine from pollen grains. The remaining exines were then mounted on a slide to be observed and photographed under an optical microscope.

\section{Chromosome count}

Chromosome numbers of Lythrum thesioides were determined in January 2019, from flower buds of a cultivated individual (initially from the Campuget population). Young flower buds were fixed in a solution of absolute ethanol: glacial acetic acid $(4: 1, \mathrm{v} / \mathrm{v})$. After 2 weeks at room temperature, the fixations were stored at $-18^{\circ} \mathrm{C}$. Flower buds were then stained in $45 \%$ acetocarmine stain, boiled for $3 \mathrm{~min}$, and squashed between the microscope slide and cover glass. The chromosome count was performed in ovaries. Mitotic metaphases were drawn (Wild M20, $15 \times 100$ ) with a camera lucida, at high magnification, with ca $0.15 \mu \mathrm{m}$ error per chromosome (i.e. $1 \mathrm{~mm}$ on the paper).

(3) Population search
The projection of both former (Pazac and Jonquières Lake) and current (Campuget) populations of Lythrum thesioides onto a geological map of the Costières area showed that all sites are located on a common geological substrate (Figure 3). This geological substrate is a recent layer of sediments corresponding to clayloam that filled-in the wetland depressions of the region. This layer may be used to identify the previous location of wetlands drained during agricultural intensification in the twentieth century and which constitute potential sites for the occurrence of populations and/or seedbanks of $L$. thesioides. Fourteen different previous wetlands were identified using this method, including the Vistre valley, large wetlands (such as Campuget and Jonquières) and smaller pools. Thirty points were chosen from recent aerial photographs, with at least one point per polygon. Over a period of 3 days in June 2017 every defined point was visited to search for L. thesioides (and other temporary wetland plant species).

\section{Results}

\section{(1) Distribution of Lythrum thesioides}

All the herbarium specimens reviewed are presented in table 1 and are also located in a map in Figure 2.

\section{Central/Eastern Europe and Central Asia}

Bieberstein (1808) first described Lythrum thesioides in Russia, from the foothills of the Caucasian mountains where a few specimens, more than 200 years old, except one from 1888, are known. In Russia, a second place of collection is the "Sarepta", near the Volga River and the city of Volgograd. There are two undated specimens from Afghanistan, one from William Griffith (1810-1845) without any precise location and another by Joharchi et al. (2007) in 1987 in the Hari River valley on the border with Iran. In Iran, there is also an undated collection from Fars. In Western Asia, there is a record from Iraq in 1957 ("Singleton on damp sandbank now exposed in ruins bed", Sarsang) that is preserved at the herbarium of Edinburgh. In Central Asia, there are two specimens from Kazakhstan, one collected in 1926 (AA herbarium) the other one in 1928 from the eastern part of the country (MW herbarium). Finally, Mallaliev and Zalibekov (2018) reported a population of L. thesioides in Dagestan (Caucasian region of Russia). However, after the discussion and exchange of photos with the authors, this observation does not correspond to L. thesioides. In Central Europe, one observation is mentioned from Hungary, with a herbarium specimen in Budapest, collected in the river banks of the Danube in 1917, a few kilometers south of Budapest. 
Table 1. Herbarium specimens of $L$. thesioides in the main collections (often named as $L$. geminiflorum for French samples).Codes of herbaria: AA (Ministry of Science, Academy of Sciences, Alma-Ata, Kazakhstan), AIX (Muséum d'Histoire Naturelle d'Aix en Provence, France), ANG (Muséum des Sciences Naturelles, Angers, France), AUR (Herbier du muséum des volcans, Aurillac, France), B (Zentraleinrichtung der Freien Universität Berlin, Germany), BOLO (University of Bologna, Italy), BP (Hungarian Natural History Museum, Budapest, Hungary), CLF (Institut des Herbiers Universitaires de Clermont-Ferrand, France), E (Royal Botanic Garden, Edinburgh, UK), FUMH (Herbarium of the Ferdowsi University of Mashhad, Iran), GAP (Conservatoire Botanique National Alpin, Gap, France), K (Royal Botanic Gardens Kew, UK), L (Naturalis Biodiversity Center, Leiden, Netherlands), LE (Komarov Botanical Institute, Russia), LM (Musée vert, Le Mans, France), LYO (Université Claude Bernard, Lyon, France), MPU (Université de Montpellier, France), MW (Moscow State University, Russia), NCY (Jardins Botaniques du Grand Nancy et de I'Université de Lorraine, Nancy, France), NIME (musée d'Histoire naturelle, Nîmes, France), PC (Muséum National d'Histoire Naturelle, Paris, France), SLA (Société des Lettres de l'Aveyron, Millau, France), W (Naturhistorisches Museum Wien, Vienna, Austria).

\begin{tabular}{|c|c|c|}
\hline Place of collection & Date (of collection) & Herbarium (number of parts) \\
\hline \multirow[t]{8}{*}{ France (Jonquières) } & 1847 & MPU (2) \\
\hline & 1848 & $\operatorname{CLF}(1), \operatorname{MPU}(2), \mathrm{NCY}(1), \mathrm{P}(1)$ \\
\hline & 1849 & $P(1)$ \\
\hline & 1853 & AUR (1), SLA (1) \\
\hline & 1854 & LYO (1), MPU (1) \\
\hline & 1902 & CLF (1), GAP (2), MPU (1), NIME (6) \\
\hline & 1911 & CLF (1) \\
\hline & $?$ & MPU (1) \\
\hline France (Tresques) & 1853 & ANG (1), AUR (1), LYO (1), MPU (1), P (2), SLA (2) \\
\hline France (« next to Marseille ») & 1858 & $\operatorname{AIX}(1)$ \\
\hline France (Pazac) & 1951 & MPU (1) \\
\hline France (Les Mées) & $?(<1900)$ & $\operatorname{LM}(1)$ \\
\hline Italie (near Mantova) & 1937 & BOLO (1) \\
\hline Hungary & 1917 & $\mathrm{BP}(1)$ \\
\hline \multirow{4}{*}{ Russia (Caucasus) } & $<1808$ & B (1, Typus) \\
\hline & 1800 & LE (1, Typus) \\
\hline & 1888 & MPU (1) \\
\hline & $?$ & $\mathrm{E}(1), \mathrm{MW}(1), \mathrm{LE}(1)$ \\
\hline \multirow[t]{2}{*}{ Russia (Sarepta = Volgograd) } & 1853 & LE (1) \\
\hline & $?$ & MW (1), P (1) \\
\hline Kazakhstan ("Aktobe region") & 1926 & $\mathrm{AA}(1)$ \\
\hline Kazakhstan ("between the rivers First and Middle Tentek") & 1928 & MW (1) \\
\hline Iraq (Sarsang) & 1957 & $E(1)$ \\
\hline Iran (Fars) & 1885 & $K(1), W(3)$ \\
\hline Iran (Khorassan) & 1987 & FUMH (1) \\
\hline Afghanistan (Herat) & $?$ & $\mathrm{~K}(1)$ \\
\hline Afghanistan (?) & $?(1810-1845)$ & $\mathrm{L}(1)$ \\
\hline
\end{tabular}

\section{Western Europe}

The occurrence of Lythrum thesioides has mostly been documented in Western Europe. In Italy, two records were documented more than a century ago in the Po plain, one along the river, the other in a paddy field (Bertoloni 1842 and BOLO herbarium; Pignatti 1982). In the South of France, most observations have been reported near the Rhône valley, between Nimes and Orange (Figure 2(a)) from 1841 to 1951. The plant was observed from the Costières area, south and east of Nîmes, mostly at the Jonquières lake with eight observations from 1841 (Jordan 1847) to 1911 (Herbarium of d'Alleizette), at the Pazac lake (MPU herbarium, observation by Tallon in 1951), between Tresques and Connaux in 1853 (by l'Abbé Gonnet), in the valley of the Rhône River (Rouy and Camus 1901) which may be the same site as that mentioned by Charrel (1913) near Caderousse, and near Pierrelatte, in a "wet field" (Chatenier 1922). Two additional reports concern a vague observation that was made near Marseille in May 1858, i.e. very early in the season and this may be a reference to Jonquières lake ( $<80 \mathrm{~km}$ away), and in the Durance valley, near Paillerols (Les Mées, Alpes-de-HauteProvence) but with no date (herbarium Rendu, Le
Mans). A final dubious observation of L. thesioides was recorded from South West France near Itxassou in 1880 , although there is no herbarium specimen and the description of the plant and the vegetation community suggests that this was an observation of Lythrum hyssopifolia, with geminate flowers (Gillot 1880).

In 1998, 47 years after the last observation in France, Michaud and Molina (1999) reported roughly 100 individuals of Lythrum thesioides mixed with Lythrum tribracteatum Salzm. ex Spreng. in a cultivated melon field at the edge of the lake of la Capelle. A few plants were also observed in 2009 in a deep ditch ( $3 \mathrm{~m}$ deep) that had been recently dug for irrigation purposes (SILENE 2019), adjacent to the previous melon fields. However, since the end of melon cultivation, the site has changed into a perennial meadow grazed by horses and L. thesioides has not been observed since (Girardin 2011), despite annual visits to the site.

Twelve years later, a new population was discovered in Campuget (Manduel, Gard, France), in July 2010 at Campuget (Manduel, Gard), in the context of an Environmental Impact Assessment realized for the construction of a new high-speed train line. More than 100 individuals of Lythrum thesioides and 


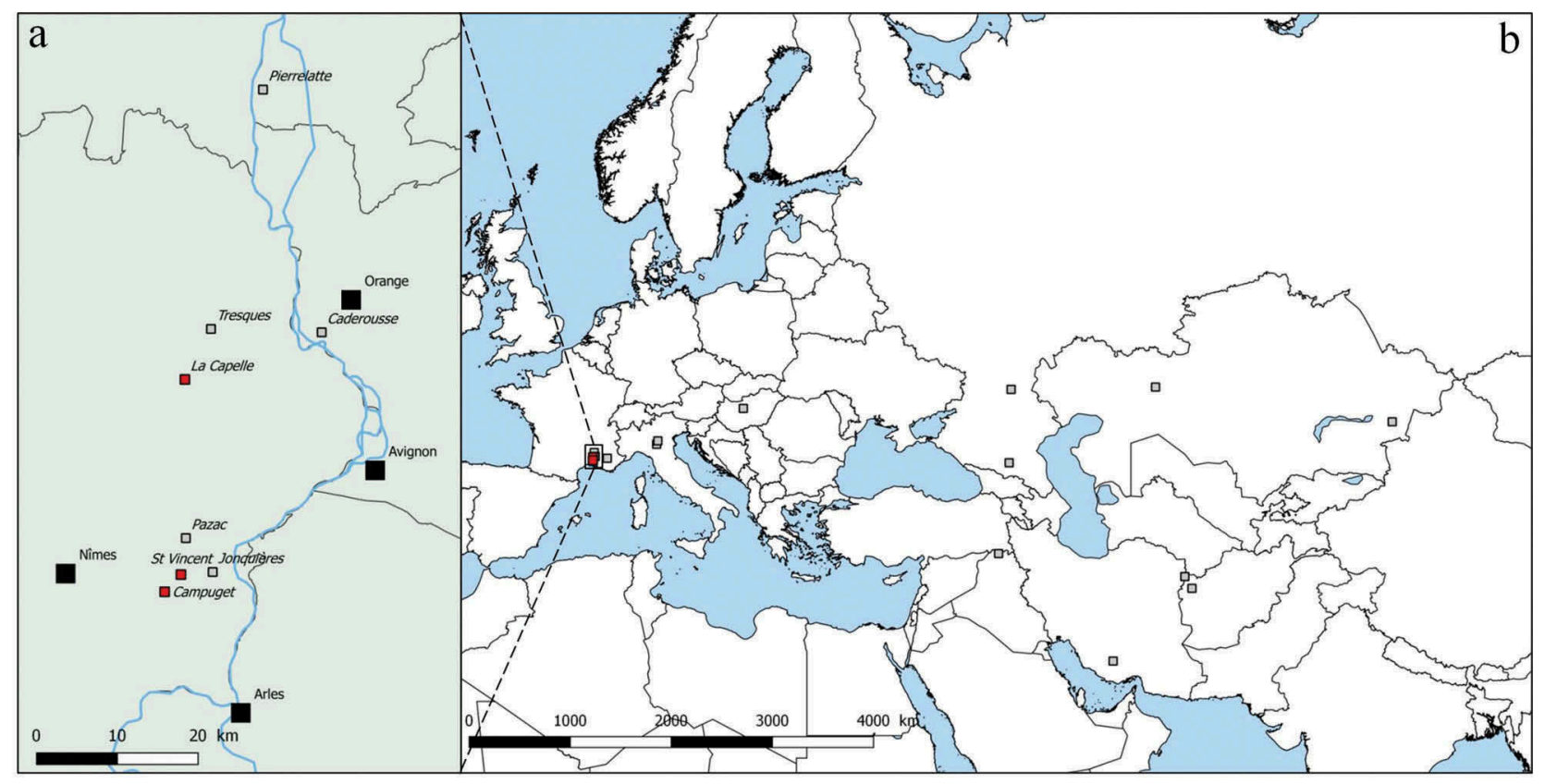

Figure 2. Distribution map of Lythrum thesioides based on former and current observations. (a) Low Rhone Valley zoom, (b) Eurasian distribution.

Black squares represent principal cities; red squares are recent observations of $L$. thesioides (post 2000); grey squares are historical observations of L. thesioides (before 2000).

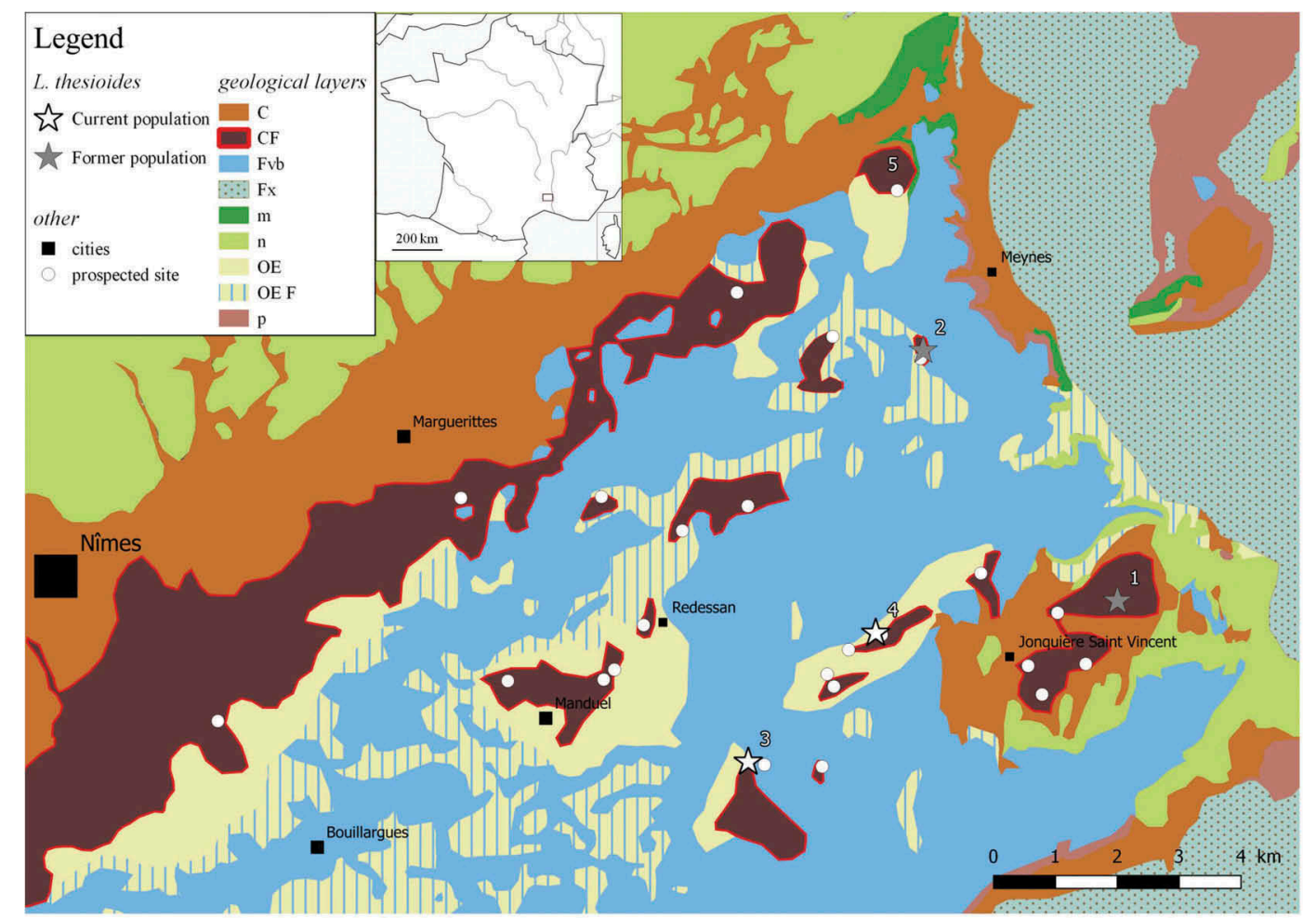

Figure 3. Geological map of the Costières area. Numbers: (1) Jonquières, (2) Pazac, (3) Campuget, (4) St Vincent, (5) Clausonne (not a population of L. thesioides).South of Nîmes: the largest polygon of CF layer represent the valley of the Vistre (small river). Geological layers, according to a simplified geological map (from BRGM, map 965, Nîmes, 1/50,000). C: colluvial deposits (Quaternary) CF: filled-basins: grey silts and limestone (Quaternary), Fvb: detrital formation (« Cailloutis villefranchien »), Fx: alluvium (Quaternary), m: marl and molasse, n: limestone, OE: loessal silts: thick layer (Quaternary), OE F: loessal silts: thin layer or discontinuous on Fvb (Quaternary), p: clay.

thousands of individuals of both Lythrum tribracteatum and Lythrum hyssopifolia L. were observed in this site. The three species grew in large ruts created by heavy machinery employed for an archaeological survey. The wetland of Campuget was originally a large temporary lake (around $120 \mathrm{ha}$ ), grazed by sheep. But agriculture and drainage strongly modified the landscape until the abandonment of agriculture 
around 2000 (Pirsoul et al. 2014). Since then, vegetation has developed spontaneously in the context of a modified hydrology with limited management to control tree encroachment after the discovery of the L. thesioides population.

(2) Species description

\section{Field and culture observations}

The isolated individual of Lythrum thesioides produced fruits and viable seeds (capable of germination). No insect were observed visiting flowers during our experiment. Flowers stayed open only during the day and closed at night (closed at 7 am and 9 pm) preventing pollination by moths and other nocturnal insects. The life-span of the flowers is very short and petals usually fall after 1 or 2 days. Capsules are $2 \mathrm{~mm}$ long et $1 \mathrm{~mm}$ wide, containing $39 \pm 13$ tiny light brown seeds, about $15 \pm 1.5 \mu \mathrm{g}$ each (Figure $1(\mathrm{~g})$ ).

\section{Pollen observations}

The pollen of Lythrum thesioides is similar to that of L. borysthenicum (M.Bieb.ex Schrank) Litv., with heterocolpate grains. There are six furrows (ectoapertures), three of them doubled with a pore (endoaperture). The size of the pollen was about 20 $\mu \mathrm{m}$ of diameter (Figure 1(f)).

\section{Chromosome count}

A chromosome count revealed $2 n=30$. Considering $\mathrm{X}=5$ (Graham and Cavalcanti 2001), this indicates a hexaploid karyotype. The poor quality of the mitotic metaphase plates prevented further analysis.

\section{(3) Population search}

Site visits revealed the globally poor habitat quality and conservation status of wetlands of the Costières area that have all been drained and cultivated. Thirteen sites hosted wetland species but only five (17\%) can be considered as temporary pool communities. Wetland plant communities were mostly in ditches, where the hydrology is slightly similar to temporary wetlands.

Prospections of the Pazac and Jonquières lakes where Lythrum thesioides was previously reported were unfruitful, no sitings were reported. Nevertheless, the plant was observed in the recently discovered population of Campuget, as in every year since its discovery in 2010. Of the 30 sites visited in the Costières territory, one new population of L. thesioides was detected, at Saint-Vincent (Jonquières-Saint-Vincent, Gard) in a wet depression near to the historical site of Jonquières Lake $(4 \mathrm{~km}$ distant). It was found in a very recently enlarged ditch in an otherwise intensive agricultural context. In June 2017, this population comprised less than 30 individuals of $L$. thesioides all located along a $200 \mathrm{~m}$ long ditch. During the second visit in September, about 250 individuals were observed, several being very tall (50 cm high) and each of those with more than 500 fruits. Monitoring started in 2017 with the discovery of this new population, using presence absence data in order to begin a study of the population dynamics of both Saint-Vincent and Campuget populations.

\section{Discussion}

The historical description of this species is limited to the discrimination between $L$. thesioides and L. thymifolia $L$. concerning notably the presence of pedicel and the shape of the capsule for Western European samples of the former species (Bieberstein 1808), but did not mention geminate flowers, for example. The first mention of geminate flowers was made later (Bertoloni 1842), leading to the description of a new species, L. geminiflorum Bertol. 1842, which was later included within L. thesioides. However, the observation of the typus (Berlin herbarium), revealed that this sample has few geminate flowers. It can, however, be distinguished from other Lythrum species by its elongated pointed leaves, and its small, slightly bell-shaped flowers, mostly geminate. Our study completes the description of the species with the pollen and karyotype $(2 n=30)$ description, and measures on capsule and seeds.

\section{An ephemeral species in a disturbed environment}

Lythrum thesioides has been poorly recorded during the last two centuries, since its first description. Indeed, despite a large known potential distribution, from Central Asia to Western Europe, the plant has been recorded less than 30 times. Even though a taxonomical issue with L. linifolium Kar. \& Kir. 1841 exists, the latter has no recent and very few historical observations (Koehne 1884, Taran 1993; Mesterházy 2017). Thus, the three recent observations described in this paper from the South of France represent the only currently known populations (i.e. observed in the last 20 years) of L. thesioides world-wide.

It appears that this species has always been rare and erratic. Except in Jonquières Lake, where it was documented 8 times from 1841 to 1911, all other historical records were made in only a single year. In 1853, the Abbé Gonnet wrote on his herbarium specimen from Tresques (Gard), conserved in Jean Henri Fabre's herbarium (SLA herbarium) "This species has not appeared since even though there were hundreds of thousands growing plants in this place. It also disappeared from the Jonquières Lake " (translated from french). This note futher indicates the ephemeral character of this species. 
For recent observations, the species was seen in $\mathrm{La}$ Capelle only in 1998 and in 2009. Campuget is the only known place where the species has been observed annually since 2010, in and around artificial pits that were dug as part of an archaeological survey. At the Saint-Vincent site, our monitoring (unpublished data) suggests that the population appeared with a high rate of occupancy after a major physical disturbance (enlargement of the pit) that removed all vegetation, and that the species may not reappear in the absence of disturbance.

The plant only grows in late-flooded habitats. Indeed, it flowers late in the season, starting in early summer. The germination of seeds starts only at high temperatures $20-25^{\circ} \mathrm{C}$ (Gazaix in prep) which occur in late spring in the South of France. Ecosystems with late flooding conditions are uncommon under a Mediterranean climate regime and this germination niche is more typical of continental species (Deil 2005; Carta 2016). The most suitable habitat of Lythrum thesioides is thus in the large temporary lakes that have occurred in the Costières territory (where it occurs at the edge of fluctuating water bodies) or along the temporarily flooded edge of rivers with high spring water-flows. Plants of $L$. thesioides grow in the external belt of the lake in la Capelle, and on the edge of the lake in Jonquières (note in herbarium specimen: "Bord de l'étang"). In Campuget, a recent mapping of the seed bank of L. thesioides according to the topography of the wetland reveals a peripheral distribution of the seeds (Gazaix in prep.).

The other important parameter for the appearance of Lythrum thesioides appears to be a disturbance that reduces or eliminates plant competition and improves light irradiance at ground level. Indeed, the three recently discovered populations were located in highly disturbed sites with soil perturbations and a modified hydrology involving late floods in common with all the other observations. At la Capelle, the population was found within melon fields, involving soil ploughing and irrigation across the drained part of the lake. The lake of la Capelle is one of the very few large Mediterranean temporary pools that still exists in France and the only current natural body of water of the Gard department (Gayte 1991), even though it has been partially drained. At Campuget and SaintVincent, plants were found on recently dug or enlarged pits and in machine tracks. In some historical records, disturbance is also present, e.g. in ricefields (Pignatti 1982) or in fields next to rivers (Chatenier 1922). Finally, natural rivers provide strong disturbances and create mudflats or sandbanks where L. thesioides can grow (historical observations in the Rhone, Durance, Danube, Volga, ...). In these fluctuating habitats, the seed bank can stay buried for decades (van der Valk and Davis 1978; Brock 2011; Poschlod and Rosbakh 2018). Thus, the most probable hypothesis is that the seed bank has remained after drainage in La Capelle, Campuget and Saint-Vincent sites, and that recent disturbances have stimulated germination of $L$. thesioides seeds.

The distribution of seeds is also explained by the localization of adult individuals (Metzner et al. 2017), and Lythrum thesioides may be excluded from deeper positions by long periods of flooding and/or the presence of other more competitive or better-adapted species, hence its position in the external ring, where only wet years allow the germination of its seeds. Very wet years may appear as a form of disturbance, by flooding of non-adapted vegetation, and be complemented by local disturbance, such as wild boars that turn the top soil (Amami et al. 2009). This pattern of distribution has been indicated for other species of temporary pools (e.g. Elatine brochonii Clavaud, Pilularia minuta Durieu), that only grow in wet years (Rhazi et al. 2009) and do not have propagules distributed in the deepest part of the wetland.

\section{Conservation status}

Temporary pools and river bank habitats are threatened by artificialisation (Brinson and Malvárez 2002). Most large rivers of Europe and Central Asia have suffered from flow regulation and human activities (Dynesius and Nilsson 1994; Ward 1998), and temporary pools have disappeared dramatically as a result of agriculture intensification and urbanization (Bouahim et al. 2014). The Costières territory has incurred and still faces these threats. In this territory, drainage started some 2,000 years ago, when the Clausonne lake (Figure 3) was drained by the Romans to build the aqueduct that was to bring water from Uzès to Nîmes, via the famous "Pont du Gard" (Fabre et al. 1997). Since that time, agricultural development has caused temporary pools to dwindle in size and number and become highly modified in their hydrological regime and poor in quality (Molinier and Tallon 1948)

Jonquières lakes, which hosted Lythrum thesioides was drained at the beginning of the XIX century (Toulemonde 2003), Pazac and Campuget were drained and cultivated later in the 1950s and 1960s. For the 14 wetlands that we visited to prospect the presence of L. thesioides (and other rare species) using the geological map of the Costières territory, all have been drained at least partially. This loss of temporary wetlands in the Costières was reported several decades ago when Molinier and Tallon prospected wetlands previously visited by de Pouzolz a century before (Molinier and Tallon 1948). In Campuget, a network of pits currently drains the wetland, although the land is partially managed by the regional Nature conservation organization (Pirsoul et al. 2014). In Saint-Vincent, changes in agricultural practices in 2017 and 2018 such as plantations of peach trees and 
Populus nigra hedgerows and the pumping of groundwater represent new threats for the conservation of L. thesioides, not to mention ongoing use of herbicides. At La Capelle, recently dug big pits have disconnected the field from the water of the lake, probably preventing germination of $L$. thesioides seeds, which was previously stimulated by the irrigation of the melon field (Guéniot and Klesczewski 2018).

The conservation status of the species was assessed as "Endangered" by the IUCN at the Mediterranean (Diadema 2010) and European (Lansdown 2011) scales. Although a global assessment is lacking, and the fact that these evaluations were made without the knowledge of the discovery of two new populations of the species at Campuget and Saint-Vincent, the poor conservation status of the three current populations should justify the maintenance of an endangered status for this species.

Recent projects on Mediterranean temporary pools have led to the discovery of new populations of rare plants in this ecosystem (Daoud-Bouattour et al. 2009; Porto et al. 2012; Ghrabi-Gammar et al. 2017; Minissale et al. 2017; Lotterman et al. 2018). Our recent observations on Lythrum thesioides are another example of discovery of new populations and will contribute to improve our capacity to implement conservation management for this species.

Even though some wetlands were drained decades ago, restoration programs can still be envisaged, as has been done for pools filled more than a century before in England (Alderton et al. 2017). The search for reports of seeds and growing plants of $L$. thesioides in old records (like Jonquières, Tresques, Pazac for France, or elsewhere in other countries) is thus a priority in the examination of sites for restoration and the collection of seedbanks. Arguably, this may be easier in France as precise information on locations is available for several wetlands (Tresques, Pazac and Jonquières). Indeed, soil samples from Jonquières and Pazac have already been tested for the presence of a seed bank, but without any germination success for Lythrum thesioides (unpublished data). This failure may be due to a small sample size and a larger sampling programme may be necessary to maximize the chances of detecting viable seeds of $L$. thesioides, as was the case for the detection of the rare Centaurium favargeri Zeltner, on river banks in the South of France (Huc and Jacob 60).

Future prospections of $L$. thesioides in relation to geological substrate could help find potential populations in sites that were once temporary pools and wetlands, as we have shown by the new discovery at the Saint-Vincent site. River banks could also be surveyed. However, as the presence of such rare ephemeral species is difficult to predict (Nilsson et al. 1988), a large amount of field work, and a certain amount of luck, will be required to find new $L$. thesioides populations.

\section{Acknowledgments}

We thank Hugo Fontès \& Solène Baillet for their help in the discovery of $L$. thesioides in 2018. Attila Mesterhazy and Adrew Efremov provided information and helped with the distribution of $L$. thesioides.

\section{Disclosure statement}

No potential conflict of interest was reported by the authors.

\section{Funding}

This work was supported by the SNCF Réseau and Oc'Via.

\section{Notes on contributors}

Antoine Gazaix is a $\mathrm{PhD}$ student working on the conservation of annual Lythrum of temporary pools. He is mostly interested in the ecology of Mediterranean temporary pools, and he is working at the interface between research and conservation managers. He wrote the most part of the manuscript and worked on the population historical distribution and the population search in the Costières region.

Mario Klesczewski works since 2002 as project manager and scientific director (flora and vegetation) at the Conservatoire d'espaces naturels du Languedoc-Roussillon (CEN L-R). His work mainly focuses on conservation and management of endangered plant species and vegetation types in Southern France. The sustainable conservation of Mediterranean temporary ponds is a major axis of CEN L-R's work strategy. Mario provided information for the conservation management of this species.

Michel-Ange Bouchet, $\mathrm{PhD}$ in Natural Sciences at the University of Marseilles (1993) and CEFE/CNRS laboratory in Montpellier in Plant Ecology, Vegetation Dynamics. He was Bird Surveyor at LPO (French Organization for the Protection of Birds), and now is an Environmental consultant at BIOTOPE Mediterranean Agency since more than 20 years.Ornithologist and botanist specialized in Western European and Mediterranean flora, he is doing field inventories of rare plant species in North Africa for the International Union for Conservation of Nature. He discovered the population of Campuget, and helped write the manuscript.

Manuel Cartereau is a MSc student working on plant ecology and evolution with a special interest in the biogeography of the Mediterranean flora. Combining different approaches such as phylogeography, phylogenetics and phylogenomics, cytogenetics, environmental niche modelling and phenotypic traits, he tries to understand the impact of past, current and future global changes on plant biodiversity patterns at various biological and spatio-temporal scales. He is also particularly interested in the implications of these findings in conservation biology. He made the chromosome count of $L$. thesioides and wrote the methods and results.

James Molina is botanist, and regional director at the CBNMed. $\mathrm{He}$ is interested in the conservation of the Mediterranean Flora, particularly in Mediterranean temporary ponds ecology. He re-discovered the species in France in 1998 (La Capelle). He worked on the historical distribution of the species in France. 
Henri Michaud is botanist in the CBNMed since 1995, his interest is in the chorology and biology of Mediterranean species, as well as the biology of their conservation. He rediscovered the species in France in 1998 (La Capelle) with James Molina.

Serge D. Muller is Maitre de Conférences at Université de Montpellier, where he teaches botany and paleoecology. His research (palynology and botany) deals with the origin and developmental history of Mediterranean wetlands, specifically in Maghreb, with the aim to provide a historical background to the conservation of species and communities. He made the description of the pollen of $L$. thesioides, and wrote this section.

Lionel Pirsoul is land manager at the Conservatoire d'Espaces Naturels Languedoc-Roussillon. He is in charge of the ecological and agricultural compensation of the project of the high speed railway between Nîmes and Montpellier. He worked on the historical context of the Costières region.

Perrine Gauthier is a research engineer, interested in dynamic and conservation of plant species in the Mediterranean region. She is working at the interface between research and management, and also working for the transfer of experiences and results of her research to the land management organisms. She helped with the redaction of the manuscript.

Patrick Grillas is the scientific director of the Tour du Valat, research institute for the conservation of Mediterranean wetlands. He has an experience of more than 20 years in Mediterranean temporary wetland ecology, mostly interested in vegetation characteristics. $\mathrm{He}$ is also strongly involved in conservation organism advising, such as botanical conservatories or the LPO (Ligue pour la Protection des Oiseaux). He helped write the entire article and helped designing the population search.

John D. Thompson is a research director with the CNRS at the Centre d'Ecologie Fonctionnelle et Evolutive in Montpellier and works on the ecology, adaptation and conservation of Mediterranean endemic plants in close collaboration with protected areas and conservation management staff. In 2005 he published "Plant Evolution in the Mediterranean" with Oxford University Press. He participated in the initial idea for this paper and helped write the entire manuscript.

\section{ORCID}

Antoine Gazaix (D) http://orcid.org/0000-0002-0782-274X

\section{References}

Alderton, E, CD Sayer, R Davies, SJ Lambert, JC Axmacher. 2017. Buried alive: aquatic plants survive in "ghost ponds" under agricultural fields. Biol Conserv. 212:105-110. doi:10.1016/j.biocon.2017.06.004

Alvarez, M, J San Martín, U Deil. 2012. Nanism and ephemerism as reasons for a hidden abundance in vernal pool plants: the example of Lepuropetalon spathulatum in Chile. Feddes Repert. 123(1):55-66. doi:10.1002/fedr.201200016

Amami, B, L Rhazi, S Bouahim, M Rhazi, P Grillas. 2009. Vegetation recolonisation of a Mediterranean temporary pool in Morocco following small-scale experimental disturbance. Hydrobiologia. 634(1):65-76. doi:10.1007/ s10750-009-9895-5
Aponte, C, G Kazakis, D Ghosn, VP Papanastasis. 2010. Characteristics of the soil seed bank in Mediterranean temporary ponds and its role in ecosystem dynamics. Wetlands Ecol Manage. 18(3):243-253. doi:10.1007/ s11273-009-9163-5

Bertoloni, A. 1842. Flora Italica, Vol. 5: sitens Plantas in Italica Et in Insulis Circumstansibus Sponte Nascentes, Bononiae. [Spontaneous plants of Italy and its islands].

Bieberstein, FM. 1808. Flora Taurico Caucasica: exhibens stirpes phaenogamas, in Chersoneso taurica et regionibus caucasicis sponte crescents. [Flora of Crimea and Caucasia: phanerogam with roots, spontaneous found in the Caucasian region and the Crimea]. Charkouiae: Typis Academicis.

Bouahim, S, L Rhazi, B Amami, A Waterkeyn, M Rhazi, ER Saber, A Zouahri, M Van Den Broeck, SD Muller, L Brendonck, et al. 2014. Unravelling the impact of anthropogenic pressure on plant communities in Mediterranean temporary ponds. Mar Freshwater Res. 65(10):918-929. doi:10.1071/MF13194

Braun-Blanquet, J. 1935. Un joyau floristique et phytosociologique "l'Isoetion" mediterrannéen". [A floristic and phytosociologic jewel, the Mediterranean Isoetion]. Bull Soc 'Étud Sci Nat Nîmes Gard. 47:1-23.

Brinson, MM, AI Malvárez. 2002. Temperate freshwater wetlands: types, status, and threats. Environ Conserv. 29 (2):115-133. doi:10.1017/S0376892902000085

Brock, MA. 2011. Persistence of seed banks in Australian temporary wetlands. Freshw Biol. 56(7):1312-1327. doi:10.1111/j.1365-2427.2010.02570.x

Carta, A. 2016. Seed regeneration in Mediterranean temporary ponds: germination ecophysiology and vegetation processes. Hydrobiologia. 782(1):23-35. doi:10.1007/ s10750-016-2808-5

Charrel, L. 1913. Flore de la Provence Centrale (Bouche du Rhone, Var, Vaucluse) ou catalogue raisonné des plantes vasculaires de cette région, imprimerie Morici. [Flora of central provence (Bouche du Rhone, Var, Vaucluse) or catalogue of vascular plants of this region.] Fascicule 12. Toulon.

Chatenier, C. 1922. Plantes nouvelles, rares ou critiques du bassin moyen du Rhône". [New plants, rare or critical of the middle basin of the Rhone]. Bull Soc Bot France. 69 (5):710-718. doi:10.1080/00378941.1922

Coste, H. 1906. Flore de la France-Tome II. [Flora of France-Tome II]. Paris: Librairie des sciences et des arts.

Council of Europe. 1992. Council directive 92/43/EEC on the conservation of natural habitats and of wild fauna and flora, Official Journal L 206.

Daoud-Bouattour, A, SD Muller, H Jamaa Ferchichi-Ben, Z Ghrabi-Gammar, L Rhazi, AM Gammar, MR Karray, I Soulié-Märsche, H Zouaïdia, G de Bélair, P Grillas, S B Saad-Limam. 2009. Recent discovery of the small pillwort (Pilularia minuta Durieu, Marsileaceae) in Tunisia: hope for an endangered emblematic species of Mediterranean temporary pools? C R Biol. 332 (10):886-897. doi:10.1016/j.crvi.2009.07.004

Deil, U. 2005. A review on habitats, plant traits and vegetation of ephemeral wetlands - a global perspective. Phytocoenologia. 35(2-3):533-705. doi:10.1127/0340269X/ 2005/0035-0533

Diadema, K 2010. Lythrum thesioides. The IUCN red list of threatened species. [Accessed 2019 Feb 15]. https://www. iucnredlist.org/species/164324/5826833

Dynesius, M, C Nilsson. 1994. Fragmentation and flow regulation of river in systems the Northern third of the world. Science. 266(5186):753-762. doi:10.1126/ science.266.5186.753 
Fabre, G, J-L Fiches, J-L Paillet. 1997. L'aqueduc antique de Nîmes et le drainage de l'étang de Clausonne: hypothèses sur le financement de l'ouvrage et sur l'identité de son concepteur." [The antic aqueduct of Nîmes and the draining of the Clausonne lake: hypothesis on the financing of the work and on the identity of the designer]. In R Bedon, editor. Les aqueducs de la Gaule romaine et des régions voisines. Pulim: Université de Limoges; p. 193-220.

Faegri, K, J Iversen. 1989. Textbook of pollen analysis. Chichester: John Wiley \& Sons.

Gallego-Fernández, JB, MR García-Mora, F García-Novo. 1999. Small wetlands lost: a biological conservation hazard in Mediterranean landscapes. Environ Conserv. 26(3):190-199. doi:10.1017/S0376892999000272

Gayte, X 1991. "Les oiseaux et les amphibiens de l'étang de la Capelle-Masmolène (Gard). [Birds and amphibians of th lake of La Capelle-Masmolène (Gard)]. Report EPHE, Montpellier.

Ghrabi-Gammar, Z, SD Muller, M Rouissi, I Ben Haj Jilani, L Rhazi, G de Bélair, S Ben Saad-Limam, A DaoudBouattour. 2017. Rumex tunetanus (Polygonaceae): rediscovery of an endangered Tunisian endemic. Phytotaxa. 296(2):118-130. doi:10.11646/phytotaxa.296.2.2

Gillot, MX 1880. Compte rendu des herborisations faites du 21 au 25 juillet 1880 dans le pays basque. [Compte rendu of the herborisations made from July the 21 to 251880 in the pays Basque]. Paper presented at the session extraordinaire de la société botanique de France, July 21-25, Bayonne.

Girardin, S, 2011. Mise à jour de la cartographie de l'habitat naturel d'intérêt communautaire prioritaire ${ }^{\star} 3170$ Gazons amphibies méditerranéens sur le site Natura 2000 FR9101402 "Etang et mares de La Capelle ». [Update of the map of the natural habitat of priority community interest ${ }^{\star} 3170$ Mediterranean wet lawns on the Natura 2000 site FR101402 "Lake and ponds of La Capelle”]. Report CEN L-R, DREAL L-R., Montpellier.

Graham, S, TB Cavalcanti. 2001. New chromosome counts in the Lythraceae and a review of chromosome numbers in the family. Syst Bot. 26(3):445-458. doi:10.1043/03636445-26.3.445

Grillas, P, P Gauthier, N Yavercovski, C Pérennou. 2004. Les mares temporaires méditerranéennes. [Mediterranean temporary pools]. Station biologique de la Tour du Valat, Arles.

Guéniot, P, M Klesczewski 2018. Suivis scientifiques sur le site Natura 2000 " étang et mares de La Capelle ". [Scientific monitoring in the Natura 2000 site "lakes and ponds of La Capelle »]. Report CEN L-R, Syndicat mixte des gorges du Gardon, Montpellier.

Joharchi, M, F Ghahremaninejad, E Vitek. 2007. New plant records for Khorassan province, Iran. Ann Nat Mus Wien. 108(B):277-301.

Jordan, A 1847. Observation sur plusieurs plantes nouvelles rares ou critiques de la France, fragment 5. [Observations on serveral new rare or criticall plants of France] Paper presented at the Société Linnéenne de Lyon, Feb 8, Lyon.

Koehne, E. 1884. Les lythrariées italiennes. [The italian Lythraceae.] Nuovo Giornale. Bot Ital. 16(1):100-104.

Lansdown, RV 2011. Lythrum thesioides. The IUCN red list of threatened species. [Accessed 2019 Feb 15]. https:// www.iucnredlist.org/species/164324/5827024

Lotterman, K, E Slootweg, N Cornips, R Barendse, N Eimers, C Quist. 2018. Exaculum pusillum (Lam.) Caruel - dwergdraadgentiaan, een fraaie onopvallende gentian uit het dwergbiezenverbond, nieuw voor Nederland. [Exaculum pusillum (Lam.) Caruel - Dwarf thread gentian, a beautiful inconspicuous gentian from the dwarf piping association, new to the Netherlands]. Gorteria Dutch Bot Arch. 40:79-90.

Mallaliev, MM, MD Zalibekov. [Маллалиев, M.M., Залибеков, М.Д.]. 2018. новые виды сосудистых растений для флоры дагестана и россии". [New species of vascular plants to the flora of Dagestan and Russia]. ботанический журнал. 103(1):122-124. doi:10.1134/ S0006813618010076

Médail, F, H Michaud, J Molina, G Paradis, R Loisel. 1998. Conservation de la flore et de la végétation des mares temporaires dulçaquicoles et oligotrophes de France méditerranéenne. [Conservation of the flora and vegetation of oligotrophic and freshwater temporary ponds of Mediterranean France]. Ecol Mediterr. 24(2):119-134.

Mesterházy, A. 2017. Egyéves füzények (Lythrum) Magyarországon : a Hyssopifolia alnemzetség hazai adatainak revíziója [Annual Lythrum species in Hungary: revision of the subgenus Hyssopifolia]. Kitaibelia. 22 (1):64-70. doi:10.17542/kit.22.64

Metzner, K, S Gachet, P Rocarpin, A Saatkamp. 2017. Seed bank, seed size and dispersal in moisture gradients of temporary pools in Southern France. Basic Appl Ecol. 21:13-22. doi:10.1016/j.baae.2017.06.003

Michaud, H, J Molina. 1999. L'étang de la Capelle. [The lake of La Capelle]. Bull Soc Bot Vaucluse. 7:8.

Minissale, P, JA Molina, S Sciandrello. 2017. Pilularia minuta Durieu (Marsileaceae) discovered in south-eastern-Sicily : new insights on its ecology, distribution and conservation status. Bot Lett. 164 (3):197-208. doi:10.1080/23818107.2017.1357051

Molinier, R, G Tallon. 1948. L'Isoetion En Costière Nîmoise. [The Isoetion in the Costieres of Nîmes]. Bull Soc Bot France. 95(7-9):343-353. doi:10.1080/00378941.1948.10834735

Morgan, V, C Leon. 1992. Datasheets of flora species for revision of appendix $\mathrm{i}$ of the bern convention. Vol. 2. Strasbourg: Council of Europe.

Nilsson, C, G Grelsson, M Johansson, U Sperens. 1988. Can rarity and diversity be predicted in vegetation along river banks? Biol Conserv. 44(3):201-212. doi:10.1016/00063207(88)90102-4

Olivier, L, JP Galland, H Maurin, eds. 1995. Livres rouge de la flore menace de France. Tome 1: espèces prioritaires.[Red book of the threatened flora of France. Tome 1: priority species]. Paris: Muséum national d'Histoire Naturelle.

Pignatti, S. 1982. Flora D'italia : volume 2. Bologna: Edagricole.

Pirsoul, L, M Klesczewski, A Rondeau, F Lépine, J Molina 2014. Zone humide de Campuget: notice de gestion 2013, préalable à l'établissement d'un plan de gestion du site. [Wetland of Campuget: management notice 2013, prior to the redaction of the management plan of the land] Report CEN L-R, Montpellier.

Porto, M, AJ Pereira, R Rego, J Farminhão, A Clemente, JL Vitorino, C Tauleigne-Gomes. 2012. Elatine brochonii Clavaud (Elatinaceae), a new species to the portuguese flora. Acta Bot Malacit. 37:173-178.

Poschlod, P, S Rosbakh. 2018. Mudflat species: threatened or hidden? An extensive seed bank survey of 108 fish ponds in Southern Germany. Biol Conserv. 225:154-163. doi:10.1016/j.biocon.2018.06.024

Rhazi, L, P Grillas, M Rhazi, JC Aznar. 2009. Ten-year dynamics of vegetation in a Mediterranean temporary pool in western Morocco. Hydrobiologia. 634:185-194. doi:10.1007/s10750-009-9893-7

Rhazi, L, P Grillas, ER Saber, M Rhazi, L Brendonck, A Waterkeyn. 2012. Vegetation of Mediterranean 
temporary pools: A fading jewel? Hydrobiologia. 689:23-36. doi:10.1007/s10750-011-0679-3

Rouy, G, EG Camus. 1901. Flore de France ou description des plantes qui croissent spontanément en France, en Corse et en Alsace-Lorraine. Tome 7. [Flora of France or description of spontaneous plants of France, Corsica and Alsace-Lorraine. Tome 7]. Société des sciences naturelles de la Charente-

Inférieure, Imprimerie Deslis Frères, Tours.

SILENE. (Système d'Information et de Localisation des Espèces Natives et Envahissantes, database of CBN méditerranéen de Porquerolles, CBN alpin, CBN des Pyrénées et de Midi Pyrénées. [Accessed 2019 Feb 15]. http://flore.silene.eu

Taran, GS. 1993. On syntaxonomy of Black Irtysh flood-plain ephemerous vegetation. Siberian J Biol. 5:79-84.

Thiers, B 2019. Index herbariorum: a global directory of public herbaria and associated staff. New York Botanical Garden's Virtual Herbarium. [Accessed May 2019]. http://sweetgum.nybg.org/science/ih/

Tison, J-M, P Jauzein, H Michaud. 2014. Flore de la France méditerranéenne continentale. [Flora of continental Mediterranean France]. Naturalia Publication, Turriers.

Toulemonde, D. 2003. Un grand chantier d'assainissement et de mise en valeur, le desséchement des marais de Jonquières du Moyen Age à nos jours. [A big work of sanitation and enhancement, the drying of the swamp of Jonquières from middle age to nowadays]. Bull Soc Hist Archéol Beaucaire. $156: 157 \& 158$.

Tutin, TG, VH Heywood, NA Burges, DM Moore, DH Valentine, SM Walters, DA Webb. 1968. Flora Europaea - Vol. 2 - Rosaceae to Umbelliferae. Cambridge University Press, Cambridge.

van der Valk, AG, CB Davis. 1978. The role of seed banks in the vegetation dynamics of prairie glacial marshes. Ecology. 59(2):322-335. doi:10.2307/1936377

Ward, JV. 1998. Riverine landscapes: biodiversity patterns, disturbance regimes, and aquatic conservation. Biol Conserv. 83 (3):269-278. doi:10.1016/S0006-3207(97)00083-9

Huc, SF Jacob. 2018. La Banque De Semence Du Sol, Réservoir Pour La Régénération. [The Soil Seed Bank, Reservoir for Regeneration]. Espaces Naturels. 62:41-42. 